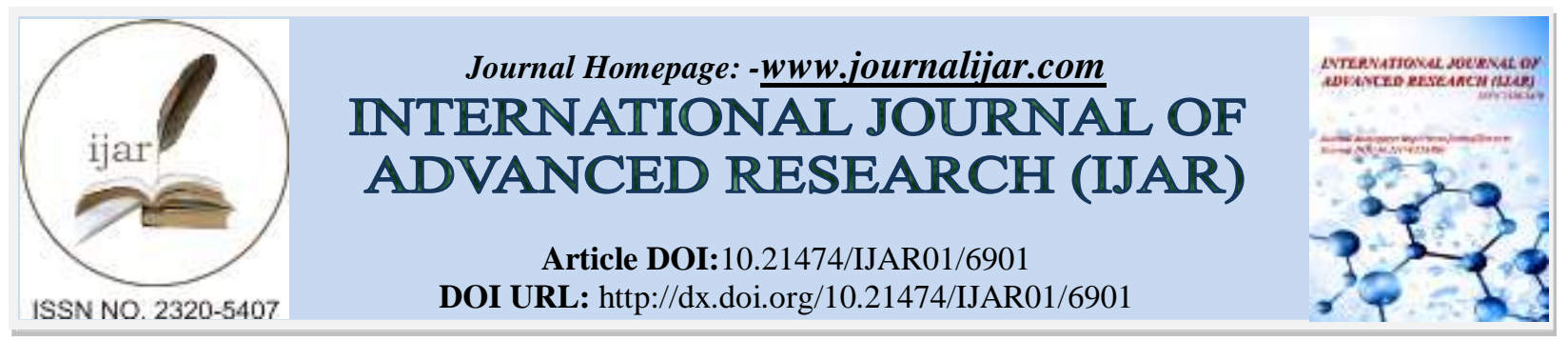

RESEARCH ARTICLE

\title{
STOCK MARKET REACTION TO THE ANNOUNCEMENT OF TOP MANAGEMENT CHANGES: PRELIMINARY FINDINGS FROM THE DAMASCUS SECURITIES EXCHANGE (DSE).
}

Zeina Al-Ahmad.

Manara University-Tishreen University, Department of Banking and Finance, Lattakia, Syria.

\section{Manuscript Info}

Manuscript History

Received: 10 February 2018

Final Accepted: 12 March 2018

Published: April 2018

Keywords:-

Top management changes, event study, DSE.

\section{Abstract}

The aim of this study is to examine the stock market reaction to the announcements of top management changes in the Damascus Securities Exchange (DSE). All announcements made by firms listed on the DSE from June 2010 to June 2017 were hand collected and only those related to top management changes and met the selection criteria were included in the sample. Following an event study methodology with different event windows, the results indicate positive abnormal returns and positive and significant cumulative abnormal returns in most of the days of the event window related to top management resignations. Surprisingly, the analysis of the trading volume reaction to top management resignations reveals negative and significant abnormal trading volumes over the event window. This could be due to the high asymmetry information associated with such type of announcements. Unlike the announcements of top management resignations, the announcements of top management appointments were not associated with any significant abnormal returns or cumulative abnormal returns. This does not appear to be driven by the equal dominance of the real and information component of the announcement as the abnormal trading volumes related to top management appointments were mainly negative and insignificant. The results, thus, suggest that the announcement of top management appointments has no information content to investors in the DSE.

Copy Right, IJAR, 2018,. All rights reserved.

\section{Introduction:-}

With the great role played by top management in determining the firm's strategy and performance, changes in top management should be viewed by shareholders as a major determinant of the firm's future performance. Therefore, investors are expected to react to the announcement of such changes. Warner et al. (1988), however, highlighted that there might be several reasons behind top management changes such as death, retirement, voluntary resignation, forced resignation (dismissal) and appointment. In fact, even the voluntary and forced resignations might be examined further on whether they followed a poor or good performance (Kind and Schläpfer, 2011), or on whether the successor is an internal or external one (Setiawan et al., 2011; Charitou et al., 2010; Dahya and McConnell, 2005). 
With the different reasons behind management changes, the direction of the market reaction to the announcements of such changes is not that clear as different types of changes could convey different signals to the market. In fact, the change itself, a change of CEO for example, could be interpreted in different ways. First, according to the common sense theory, if a member of the top management, CEO for example, somehow deviated from the firm's vision, mission, or strategic goals and thus resulted in a performance that is worse than expected, a change in the CEO should lead to better future results as the new CEO will typically take actions to improve the performance (Grusky, 1963; Dalton and Kesner, 1985; Kesner and Sebora, 1994). Therefore, from the signaling literature point of view, such a change conveys a positive signal to the market (Denis and Denis, 1995; Adams and Mansi, 2009). A change in the CEO however implies according to the vicious circle theory, major alterations to the old way in which the firm was managed. This especially holds if the CEO is an outsider, which might involve disruption to relationships with stakeholders and thus a great uncertainty about the future performance of the firm (Grusky, 1960; Beatty and Zajac, 1987; Clayton et al., 2005; Charitou et al., 2010). Therefore, the market reaction to such announcements might be negative.

The scapegoat theory (Boeker, 1992; Khanna and Poulsen, 1995) proposes that CEOs, or their subordinates in case of powerful CEOs, might be dismissed as a scapegoat for the poor performance of the corporation that is caused by factors beyond their control. If this is the case, share prices should not react to the information of changes in CEOs. Moreover, from a signaling literature perspective, Warner et al. (1988) suggest that the stock market reaction to changes of management could be the sum of two components, the information component and the real one. The information component is negative if the management change signals that the performance is worse than expected ${ }^{1}$ whereas the real component is positive as the change in management is in the benefit of shareholders' wealth. The net effect of management changes reflects the magnitude of each of these components.

Beaver (1968) suggests that stock prices reflect the average change in traders' beliefs due to the announcement. And thus, if the change in CEO contains both real and information effect of similar magnitude, then both effects would cancel out implying that the share prices do not react to the new announcement. And thus, the analysis of stock prices reaction to CEO changes might not be sufficient to determine the market reaction. In this case, trading volume might be worth examining as trading volume represents the traders' idiosyncratic reactions as suggested by Beaver (1968). In other words, it reveals the extent of disagreement amongst shareholders with regard to the nature of the announcement.

Empirically, studies that examined the market reaction to changes in top management revealed inconclusive findings. Warner et al. (1988) documented no significant reaction to the announcements of forced top management resignation in the US. Alternatively, Furtado and Rozeff (1987), Denis and Denis (1995) and Adams and Mansi (2009) amongst others documented a positive market reaction to the announcement of forced departure of top executives in the US. Li (2012) reported no significant abnormal returns to the announcement of CEO changes in the US.

Mahajan and Lummer (1993) and Neumann and Voetmann (2005) examined the market reaction to voluntary resignation in the US and Denmark respectively. They documented a negative reaction. Similarly, when Danisevska et al. (2004) examined the market reaction to voluntary and forced turnover in the Netherlands, they documented that forced turnover is associated with abnormal returns that are significantly higher than the returns associated with voluntary turnover. Kind and Schläpfer (2011) revealed that forced turnover by itself is not received by the Swiss market as a positive signal. In fact the market seems to take into account the quality of the departing CEO. Reinganum (1985) and Furtado and Rozeff (1987), using US data, could not find any significant reaction in share prices when the announcement of management departure is accompanied by the announcement of the name of the successor as the later announcement was associated with a positive price reaction. Similarly, Borstadt (1985) and Dedman and Lin (2002) using data from the US and the UK respectively, reported a negative market reaction to the announcement of CEO departure when the announcement was not associated with a reference of the successor name. Which implied that the positive price reaction around forced departure is overstated as it does not only reflect the reaction to the departure but also to the announcement of the successor CEO. Kang and Shivdasani (1996) reported that CEO turnovers were associated with positive abnormal returns in Japan. This holds regardless of

${ }^{1}$ Furtado and Karan (1990) amongst others documented that it is more likely to remove CEOs after a poor performance of the firm. 
whether the successor is internal or external. On the contrary, Charitou et al. (2010) examined the US market reaction to the appointment of an external CEO, they documented a positive reaction when an external is appointed as a CEO. Similarly, Setiawan et al. (2011), using data from Indonesia, reported a positive market reaction to the appointment of external CEOs and an insignificant one to that of internals. Lassoued and Attia (2013) documented a negative market reaction to the appointment of external and internal CEOs in Tunisia in the post revolution era. Byrka-Kita et al. (2017) examined the share prices reaction to CEO appointments in the Warsaw Stock Exchange. They reported a negative market reaction to the announcement.

The majority of studies examined the market reaction to the announcement of changes in top management in developed markets, this study contributes to the literature of market reaction to top management changes as it provides evidence from the DSE, one of the most nascent markets in the MENA region, where only a few research has been conducted. Moreover, it uses a unique data set where the announcements of resignations are not coinciding with the appointment ones which enables examining the pure reaction to each type of announcements. The empirical findings of the study should be helpful to individual and institutional investors in terms of developing their investment strategies.

The remainder of this study is organized as follows, section 2 provides a snapshot on the institutional framework of the DSE, section 3 presents and clarifies how the data was collected and explains the methodology, section 4 presents and discusses the findings, and section 5 concludes the study.

\section{The Institutional Framework of the DSE:-}

The Damascus Securities Exchange was launched in March 2009 with six firms only. This has changed later on as the size of the market increased to reach 24 listed firms in 2017. In January 2010 the DWX index was launched. The index is a value weighted index of all firms listed on the DSE.

The DSE is regulated by the Syrian Commission on Financial Markets and Securities (SCFMS), an independent regulatory entity, responsible for controlling, developing and organizing the stock exchange and all its related activities including disclosure, stock issuance and trading. As is the case in other stock markets, the SCFMS requires the disclosure of any price sensitive information by listed firms. Changes in management are amongst the information required by the SCFMS to be disclosed by listed firms.

In 29-6-2008, the SCFMS issued its corporate governance act, the act was to become compulsory for all public limited corporations by 2009. The act is strongly built on the OECD and Sarbanes Oxley Act of 2002 (Al-Ahmad, 2011) where the majority of the board of directors consists of non-executives and third of the board members at least should be independent in addition to the separation between the chairman and the CEO positions.

According to article 11 of the corporate governance act, it is clearly stated that "as the board of directors enjoys all the necessary powers and competencies to manage the company, it is responsible for the business results of the company, even if it has formed committees or delegated tasks to other persons". Thus, changes in the chairman, and not only in the CEO or the general manager, should convey a signal to the market about the past and future performance of these corporations.

Like other developing markets, the DSE is characterized by thin trading where there could be many days without any trading. The DSE deals with thin trading by applying the Maynes and Rumsey (1993) method namely the "lumped" method. This method involves recording the last closing price as the price on days where no trading takes place. Despite its limitations, Bartholdy et al. (2003) pointed out that this method is easy to apply and one of the most frequently used methods to adjust for thin trading.

\section{Data and methodology:- \\ Data:-}

All announcements that were published on the DSE website were examined. Hundred and ninety announcements were disclosed during the period of interest. The announcements could mainly be classified into: changes in board of directors and top management, operational risk-mainly fraud-, changes of location, transfer from one market to another, and miscellaneous announcements. Amongst the whole population of announcements those related to top management changes were chosen. Changes in top management are defined as appointments or resignations in the chairman, CEO, or general manager. Classifying resignations into forced or voluntary was not possible as the 
reasons behind all resignations were referred to as "personal reasons". In fact, Clayton et al. (2005) reported that forced turnovers are not that common and accounted for only $17 \%$ of all turnover announcements in their sample. Similarly, Worrell et al. (1986) reported that management usually prefers to treat forced disclosure with discretion and to announce it as a voluntary one in order to avoid the negative market reaction that could result from such announcements.

Not being able to separate voluntary resignations from forced ones, all resignations were included in the sample under the heading top management resignations. Grouping the two types of resignation announcements is not expected to affect the results as Khanna and Poulsen (1995) reported that managers of poorly performing firms may voluntarily resign in order to avoid being sued by shareholders, and thus even the voluntary resignation might give the same signal as the forced one. Moreover, given the small size of the sample, separating voluntary resignations from forced ones would lead to a smaller size of the sample.

Changes in management due to retirement, death and illness are excluded from the sample as they are unlikely to be internal mechanisms for removing poorly performing managers. At first 15 announcements of appointments and 8 announcements of resignations were obtained. Afterwards, these announcements are filtered further whereby any announcement that was confounding with another one was excluded from the sample in order to avoid the possibility that the market reaction might be caused by the overlapping event rather than the management change one. Moreover, amongst the remaining announcements, announcements where no trading took place during the estimation period or the event period were also excluded from the sample. This resulted in a final sample of 10 appointment and 5 resignation announcements.

\section{Methodology:-}

To examine the stock market reaction to the announcements of top management changes, an event study approach was followed. Event studies were first developed by Ball and Brown (1968) and Fama et al. (1969). The first step in an event study is to identify the event day, day zero, which is the day at which the announcement is made. Stock returns however may fail to fully reflect the available information at the event day (Campbell et al., 1997), therefore after defining the event day, an event window must be defined. This window represents the period over which the stock returns are expected to change due to the event and it usually includes days before and after the announcement. The reason for including pre announcement data is attributed to the fact that the information conveyed to the market in the event day might have been already known by the market before the event took place (leakage of information) whereas the post-event data is examined because stock prices might be slow in reflecting the upcoming information. Taking into account that the DSE is a nascent market where stock prices might not fully reflect the upcoming information, the event window is chosen to be -30 days before the event and +30 days after the event.

Having defined the event window, one needs to know whether the event window experienced abnormal returns where the later is defined as the difference between the actual returns over the event window and the normal returns over the same window. Normal returns are those expected by the market model had the event, or any other event, not taken place. ${ }^{2}$ To estimate the parameters of the model and calculate the normal returns, the market model is run using actual data of the firm returns and the market returns over a period of 150 days to 31 days prior the announcement. ${ }^{3}$

$R_{i t}=\alpha_{i}+\beta_{i} R_{m t}$ Equation (1)

Where:

$R_{i t}$ are the actual returns of firm i on day $\mathrm{t}$ which could be any day from day -150 to day -31 prior to the event day.

$R_{m t}$ are the actual returns of the market on day $\mathrm{t}$ which could be any day from day -150 to day -31 prior to the announcement of the firm $i$.

$\alpha_{i}$ and $\beta_{i}$ are the model parameters that should be estimated.

\footnotetext{
${ }^{2}$ Despite being so simple, the Market model according to Brown and Warner $(1980,1985)$ is easy to apply and generates results that are very close to that of applying more sophisticated models.

${ }^{3}$ This period is called the estimation window and it should not overlap with the event window $(-30+30)$.
} 
After applying the model in equation (1) and estimating $\alpha_{i}$ and $\beta_{i}$, the estimated $\alpha_{i}$ and $\beta_{i}$ are used along with the market returns over the event window to calculate the normal returns that are expected to occur over the event window.

After calculating the normal returns, the abnormal returns are calculated as follows:

$A R_{i t}=R_{\text {itn }}-R_{\text {ita }}$ Equation (2)

$A R_{i t}$ are the abnormal returns of firm $\mathrm{i}$ on day $\mathrm{t}(\mathrm{t}=-30$ to +30 where $\mathrm{t}=0$ is the event day).

$R_{i t n}$ are the normal returns of firm i on day $\mathrm{t}$.

$R_{\text {ita }}$ are the actual returns of firm i on day $\mathrm{t}$.

After calculating the abnormal returns for each announcement on each day of the event window, the cumulative abnormal returns are calculated, to do so, first the average abnormal returns for all announcements on day $t$ are calculated as follows:

$A A R_{t}=1 / n \sum_{i=1}^{n} A R_{\text {it }}$ Equation (3)

Where $A A R_{t}$ are the average abnormal returns for all announcements of firm (i) on day t. Afterwards the CAR is calculated as follows:

$C A R_{T}=\sum_{t=-30}^{30} A A R_{t}$ Equation (4)

The statistical significance of the CAR is assessed following the Brown and Warner (1980) crude dependence adjustment $\mathrm{T}$ test, which corrects for the cross-sectional dependence.

To calculate the abnormal trading volume, we followed Landsman and Maydew (2002) and Alves and Dos Santos (2008) where the abnormal volume for company $i$ on day $t$ is measured as follows:

$A V_{i t}=\frac{\mathrm{v}_{\mathrm{it}}-\mathrm{E}\left(\mathrm{V}_{\mathrm{it}}\right)}{\sigma_{\mathrm{it}}}$ Equation (5)

where $A V_{i t}$ is the abnormal trading volume for company $i$ on day $\mathrm{t}, V_{i t}$ is the trading volume of company $\mathrm{i}$ on day $\mathrm{t}$, $E\left(V_{i t}\right)$ and $\sigma_{i t}$ are the mean and standard deviation of the daily trading volume for firm $\mathrm{i}$ in the estimation window $(\mathrm{t}=-150$ to -31$)$.

After calculating the abnormal trading volume, the average abnormal trading volume for all announcements of firm (i) on day $\mathrm{t}$ is calculated as follows:

$A A V_{t}=1 / n \sum_{i=1}^{n} A V_{i t}$ Equation (6)

\section{Results and Discussion:-}

Results of the share price reaction to top management changes:-

The results of the event study are reported in Tables (1) and (2). Table (1) reports the share prices reaction to the announcement of management resignations and appointments. As revealed in the table the resignation announcements appear to be associated with positive average abnormal returns in most of the event window days (49 days out of 61). Interestingly the abnormal returns in the event day and in most of the pre announcement period, except day $-26(\mathrm{~T}=3.11)$ are insignificantly different from zero. Significant abnormal returns in the preannouncement period could indicate, as discussed above, a leakage in information. The abnormal returns on the post event window are insignificantly different from zero except in days $+14+15+16$ and +26 where the returns were positive and significant at the $1 \%$ level. This could indicate a delay in the stock prices reaction to the resignation announcement which is quite normal in a developing market where the stock prices might be slow in reflecting the new information.

Interestingly when examining the cumulative abnormal returns (CARs) that could accrue to investors over the event window, the results in Table 1 reveal positive and significant CARs over the event window. As shown in the table, the CAR increased steadily from day $-26(\mathrm{CAR}=0.0198)$ to day -12 (CAR=0.0602). Afterwards it declined and fluctuated for a while and then increased again in day $-2(\mathrm{CAR}=0.0620)$ where the CAR kept increasing until day +7 $(\mathrm{CAR}=0.0716)$ afterwards it declined again and fluctuated for few days but increased later on in day +26 $(\mathrm{CAR}=0.0750)$ and reached its highest on day $28(\mathrm{CAR}=0.0759)$. The pattern of the CAR could indicate that there is a leakage in information for some firms and a delay in market reaction for other firms.

Unlike the positive abnormal returns and significant CARs in the case of resignations, the abnormal returns and CARs on the event window surrounding the announcements of top manager's appointment were fluctuating between positive and negative and they were not statistically significant in any of the examined days. 
The insignificant share price reaction to the announcement of a top manager's appointment could be interpreted in several ways. First, the announcement might not be value relevant for investors, which is surprising somehow as changes in top management are supposed to cause changes in the way in which the firm is managed. Alternatively, the information is value relevant but the stock market is inefficient in the semi strong form which is quit expected in a developing market. However, since the market reacted to top manager's resignation, one cannot rely on this interpretation. Another explanation of the insignificant returns could be the equal dominance of the information and real component of the announcement. If it is the case then the trading volume around the announcement should be high as it should reflect divergence in the beliefs of investors in terms of the nature of the announcement. And thus, the trading volume reaction to top management changes is examined below.

\section{Results of the trading volume reaction to top management changes:-}

The results of the trading volume reaction to top management resignations and appointments are reported in table (2). As revealed in the table the results show negative abnormal trading volume during most of the days in the event window surrounding top management resignations (57 days out of 61). The negative abnormal trading volumes are significant in most of the days indicating that trading during the event window was significantly less than usual. Positive abnormal trading volumes were reported in days $-28,+8,+18,+22$ however, in none of these days the abnormal trading volume was statistically significant. As the event of top management resignation might be associated with great uncertainty regarding the future performance of the firm, the finding could indicate that investors are reluctant to trade after such announcement due to its mixed signals. The negative abnormal trading volume in the pre announcement period could be resulted from the leakage of information before the announcement day.

Results on the trading volume reaction to the announcement of top management appointments indicate negative abnormal trading volume in 53 out of the 61 days of the announcement period. The positive abnormal trading volumes were recorded in days $-30,-28,-23,-21,-11,-10,+6,+13$. Worth noting that apart from day +2 , the abnormal trading volumes are not statistically significant in any of the event window days.

\section{Discussion:-}

Overall it appears that the market reaction to top management appointments is weaker than that of resignations. The findings contradict the documented results whereby the announcements of top managers' appointments are associated with positive and stronger share prices reaction compared to that related to top managers' resignations (Borstadt, 1985; Dedman and Lin, 2002).

Since the weak share price reaction to top manager' appointments was not associated with high trading volume, instead the market experienced negative insignificant abnormal trading volume during the event, then one can say that the results are not driven by the equal dominance of information component and real component of the announcement. Moreover, since there was a market reaction, even though it is weak, to top management resignations, one cannot attribute the insignificant market reaction towards top management appointments to inefficiency in the market. And thus, the results are more in favor of the view that top management appointments are not perceived by the market as value relevant information.

Warner et al. (1988) pointed out that it is difficult to test hypotheses about management changes in the context of an event study. This, combined with the limitations inherited in event studies and thin trading, along with the small size of the sample, cast doubts on the reliability of the results. However the research provides some preliminary findings that contribute to the field of market reaction to top management changes in developing markets.

Table 1:-Share prices reaction to top management resignations and appointments

\begin{tabular}{|c|c|c|c|c|c|c|c|c|}
\hline \multirow{2}{*}{$\begin{array}{l}\text { Event } \\
\text { day }\end{array}$} & \multicolumn{9}{|c|}{ Resignations } & \multicolumn{4}{|c|}{ Appointments } \\
\cline { 2 - 9 } & Abnormal & T stat & CARt & T stat & $\begin{array}{l}\text { Abnormal } \\
\text { returns }\end{array}$ & T stat & CARt & T stat \\
\hline-30 & 0.009 & 1.28 & 0.0092 & $3.2029^{* *}$ & 0.01 & 0.98 & 0.0146 & 0.1094 \\
\hline-29 & 0.001 & 0.25 & 0.0097 & $2.4025^{*}$ & 0.03 & 0.95 & 0.0414 & 0.2198 \\
\hline-28 & 0.009 & 1.42 & 0.0188 & $3.7841^{* *}$ & -0.02 & -1.13 & 0.0204 & 0.0886 \\
\hline-27 & 0.000 & -0.32 & 0.0184 & $3.2193^{* *}$ & -0.02 & -1.27 & 0.0002 & 0.0008 \\
\hline Event & \multicolumn{9}{|c|}{ Resignations } \\
\hline
\end{tabular}




\begin{tabular}{|c|c|c|c|c|c|c|c|c|}
\hline day & $\begin{array}{l}\text { Abnormal } \\
\text { returns }\end{array}$ & $\mathrm{T}$ stat & CARt & T stat & $\begin{array}{l}\text { Abnormal } \\
\text { returns }\end{array}$ & $\mathrm{T}$ stat & CARt & T stat \\
\hline-26 & 0.001 & $3.11 * *$ & 0.0198 & $3.0895 * *$ & -0.02 & -0.42 & -0.0222 & -0.0745 \\
\hline-25 & 0.004 & 0.96 & 0.0242 & $3.4508 * *$ & 0.04 & 0.89 & 0.0140 & 0.0429 \\
\hline-24 & 0.002 & 1.37 & 0.0261 & $3.4393 * *$ & 0.00 & -1.75 & 0.0101 & 0.0287 \\
\hline-23 & 0.005 & 1.11 & 0.0311 & $3.8392 * *$ & 0.01 & 1.21 & 0.0195 & 0.0518 \\
\hline-22 & 0.005 & 0.97 & 0.0360 & $4.1925^{* * *}$ & -0.01 & -1.03 & 0.0081 & 0.0202 \\
\hline-21 & 0.005 & 1.42 & 0.0406 & $4.4860 * * *$ & -0.06 & -1.00 & -0.0478 & -0.1134 \\
\hline-20 & 0.003 & 1.31 & 0.0439 & $4.6202 * * *$ & -0.01 & -0.65 & -0.0532 & -0.1205 \\
\hline-19 & 0.001 & 0.78 & 0.0452 & $4.5571 * * *$ & 0.00 & -0.58 & -0.0557 & -0.1208 \\
\hline-18 & 0.003 & 1.44 & 0.0478 & $4.6222 * * *$ & 0.02 & 1.11 & -0.0338 & -0.0703 \\
\hline-17 & 0.003 & 1.41 & 0.0506 & $4.7233 * * *$ & 0.00 & 0.78 & 0.0200 & 0.0388 \\
\hline-16 & 0.003 & 0.85 & 0.0534 & $4.8128 * * *$ & 0.05 & 1.01 & 0.0223 & 0.0419 \\
\hline-15 & 0.002 & 1.29 & 0.0558 & $4.8661 * * *$ & 0.00 & 0.65 & 0.0611 & 0.1113 \\
\hline-14 & 0.001 & 0.62 & 0.0573 & $4.8461 * * *$ & 0.04 & 0.99 & 0.0775 & 0.1371 \\
\hline-13 & 0.003 & 0.96 & 0.0601 & $4.9458 * * *$ & 0.02 & 0.89 & 0.0941 & 0.1620 \\
\hline-12 & 0.000 & 0.26 & 0.0602 & $4.8226 * * *$ & 0.02 & 1.42 & 0.1065 & 0.1787 \\
\hline-11 & -0.003 & -0.75 & 0.0574 & $4.4814 * * *$ & 0.01 & 1.02 & 0.0915 & 0.1498 \\
\hline-10 & -0.004 & -1.41 & 0.0533 & $4.0572 * * *$ & -0.02 & -1.37 & 0.0860 & 0.1376 \\
\hline-9 & 0.003 & 1.60 & 0.0559 & $4.1622 * * *$ & -0.01 & -0.74 & 0.1129 & 0.1766 \\
\hline-8 & 0.005 & 1.53 & 0.0609 & $4.4316^{* * * *}$ & 0.03 & 0.92 & 0.1231 & 0.1886 \\
\hline-7 & 0.000 & -0.13 & 0.0607 & $4.3205^{* * *}$ & 0.01 & 0.76 & 0.1425 & 0.2138 \\
\hline-6 & -0.002 & -1.02 & 0.0587 & $4.1000 * * *$ & 0.02 & 0.96 & 0.1456 & 0.2143 \\
\hline-5 & -0.002 & -0.73 & 0.0566 & $3.8709 * *$ & 0.00 & 0.69 & 0.1558 & 0.2250 \\
\hline-4 & 0.001 & 1.89 & 0.0575 & $3.8616^{* *}$ & 0.01 & 0.65 & 0.1632 & 0.2314 \\
\hline-3 & 0.002 & 0.65 & 0.0591 & $3.8956 * *$ & 0.01 & 1.20 & 0.1560 & 0.2174 \\
\hline-2 & 0.003 & 1.26 & 0.0620 & $4.0180 * * *$ & -0.01 & -1.41 & 0.1500 & 0.2055 \\
\hline-1 & 0.002 & 1.93 & 0.0640 & $4.0774 * * *$ & -0.01 & -1.24 & 0.1350 & 0.1819 \\
\hline 0 & 0.000 & 0.11 & 0.0639 & $4.0062 * * *$ & -0.02 & -1.06 & 0.1462 & 0.1940 \\
\hline 1 & 0.002 & $2.15^{*}$ & 0.0658 & $4.0580 * * *$ & 0.01 & 0.77 & 0.1561 & 0.2039 \\
\hline 2 & 0.002 & 0.87 & 0.0679 & $4.1225 * * *$ & 0.01 & 0.88 & 0.1614 & 0.2076 \\
\hline 3 & 0.001 & 0.67 & 0.0689 & $4.1208 * * *$ & 0.01 & 1.61 & 0.1662 & 0.2108 \\
\hline 4 & 0.002 & 1.30 & 0.0709 & $4.1807 * * *$ & 0.00 & $1.99 *$ & 0.1652 & 0.2067 \\
\hline 5 & 0.001 & 0.44 & 0.0715 & $4.1563 * * *$ & 0.00 & -0.13 & 0.1628 & 0.2009 \\
\hline 6 & 0.000 & -0.09 & 0.0713 & $4.0888 * * *$ & 0.00 & -0.82 & 0.1469 & 0.1788 \\
\hline 7 & 0.000 & 0.23 & 0.0716 & $4.0509 * * *$ & -0.02 & -0.81 & 0.1507 & 0.1811 \\
\hline 8 & -0.007 & -1.30 & 0.0650 & $3.6337 * *$ & 0.00 & 1.17 & 0.1410 & 0.1673 \\
\hline 9 & -0.004 & -1.70 & 0.0609 & $3.3622^{* *}$ & -0.01 & -1.05 & 0.1128 & 0.1322 \\
\hline 10 & -0.001 & -0.54 & 0.0601 & $3.2764 * *$ & -0.03 & -0.90 & 0.0768 & 0.0890 \\
\hline 11 & 0.002 & 0.99 & 0.0619 & $3.3336^{* *}$ & -0.04 & -1.12 & 0.0546 & 0.0625 \\
\hline 12 & 0.002 & 0.59 & 0.0637 & $3.3896^{* *}$ & -0.02 & -1.41 & -0.0168 & -0.0190 \\
\hline 13 & -0.001 & -0.26 & 0.0628 & $3.3060 * *$ & -0.07 & -0.99 & -0.0067 & -0.0074 \\
\hline 14 & 0.001 & $4.11^{* * *}$ & 0.0643 & $3.3453 * *$ & 0.01 & 0.90 & 0.0192 & 0.0213 \\
\hline 15 & 0.002 & $4.49 * * *$ & 0.0667 & $3.4328 * *$ & 0.03 & 1.16 & 0.0018 & 0.0020 \\
\hline 16 & 0.003 & $3.80 * * *$ & 0.0701 & $3.5692 * *$ & -0.02 & -1.07 & -0.0609 & -0.0660 \\
\hline 17 & -0.003 & -0.55 & 0.0674 & $3.3945 * *$ & -0.06 & -0.91 & -0.1043 & -0.1118 \\
\hline 18 & -0.003 & -1.54 & 0.0642 & $3.2029 * *$ & -0.04 & -1.04 & -0.1736 & -0.1842 \\
\hline 19 & 0.000 & -0.12 & 0.0640 & $3.1574 * *$ & -0.07 & -0.99 & -0.2148 & -0.2257 \\
\hline 20 & 0.003 & 1.65 & 0.0674 & $3.2951 * *$ & -0.04 & -0.98 & -0.3527 & -0.3670 \\
\hline 21 & 0.000 & -0.23 & 0.0670 & $3.2411 * *$ & -0.14 & -1.01 & -0.5347 & -0.5512 \\
\hline 22 & 0.000 & 0.21 & 0.0673 & $3.2263 * *$ & -0.18 & -1.00 & -0.7104 & -0.7254 \\
\hline 23 & 0.002 & $2.50 *$ & 0.0693 & $3.2904 * *$ & -0.18 & -1.01 & -0.9108 & -0.9215 \\
\hline 24 & 0.000 & -0.05 & 0.0692 & $3.2553 * *$ & -0.20 & -1.02 & -0.8745 & -0.8769 \\
\hline Event & \multicolumn{4}{|c|}{ Resignations } & \multicolumn{4}{|c|}{ Appointments } \\
\hline
\end{tabular}




\begin{tabular}{|c|c|c|l|l|c|c|c|c|}
\hline day & $\begin{array}{l}\text { Abnormal } \\
\text { returns }\end{array}$ & T stat & CARt & T stat & $\begin{array}{l}\text { Abnormal } \\
\text { returns }\end{array}$ & T stat & CARt & T stat \\
\hline 25 & 0.000 & -0.08 & 0.0691 & $3.2221^{* *}$ & 0.04 & 1.03 & -0.7901 & -0.7853 \\
\hline 26 & 0.006 & $3.98^{* * *}$ & 0.0750 & $3.4669^{* *}$ & 0.08 & 0.98 & -0.7057 & -0.6953 \\
\hline 27 & 0.001 & 1.23 & 0.0757 & $3.4701^{* *}$ & 0.08 & 0.99 & -0.6932 & -0.6772 \\
\hline 28 & 0.000 & 0.13 & 0.0759 & $3.4493^{* *}$ & 0.01 & $2.09 *$ & -0.6795 & -0.6582 \\
\hline 29 & -0.001 & -1.39 & 0.0749 & $3.3754^{* *}$ & 0.01 & 1.41 & -0.7353 & -0.7064 \\
\hline 30 & -0.003 & $-2.10^{*}$ & 0.0715 & $3.1927^{* *}$ & -0.06 & -1.01 & 0.0146 & 0.1094 \\
\hline
\end{tabular}

Note: $* * *$, and $* * *$ indicate significance at the $10 \%, 5 \%$ and $1 \%$ level of significance respectively.

Table 2:-Trading volume reaction to top management resignations and appointments

\begin{tabular}{|c|c|c|c|c|}
\hline \multirow{2}{*}{$\begin{array}{l}\text { Event } \\
\text { day }\end{array}$} & \multicolumn{2}{|l|}{ Resignations } & \multicolumn{2}{|c|}{ Appointments } \\
\hline & Abnormal trading volume & T stat & Abnormal trading volume & T stat \\
\hline-30 & -2360.75 & -0.84 & 5494.86 & 0.63 \\
\hline-29 & -4591.64 & $-2.62 * *$ & -5186.60 & -1.78 \\
\hline-28 & 6586.449 & 0.69 & 15721.39 & 0.80 \\
\hline-27 & -4644.35 & $-2.64 * *$ & -4143.48 & $-1.85^{*}$ \\
\hline-26 & -4587.15 & $-2.62 * *$ & -3700.25 & -1.02 \\
\hline-25 & -4566.55 & $-2.59 * *$ & -1253.72 & -0.30 \\
\hline-24 & -4671.55 & $-2.67 * *$ & -2250.19 & -0.54 \\
\hline-23 & -4164.15 & $-2.21 *$ & 18360.86 & 0.80 \\
\hline-22 & -4221.34 & $-2.29 *$ & -5495.24 & $-1.90^{*}$ \\
\hline-21 & -4261.14 & $-2.31 *$ & 32694.22 & 0.86 \\
\hline-20 & -4559.34 & $-2.59 * *$ & -3292.31 & -0.88 \\
\hline-19 & -4445.54 & $-2.50^{*}$ & -1669.97 & -0.35 \\
\hline-18 & -4372.4 & $-2.40^{*}$ & -4699.03 & -1.76 \\
\hline-17 & -4582.4 & $-2.58 * *$ & -5311.20 & $-2.20^{*}$ \\
\hline-16 & -4286.4 & $-2.36^{*}$ & -6190.22 & $-2.10^{*}$ \\
\hline-15 & -1865.4 & -0.65 & -6253.26 & $-2.20^{*}$ \\
\hline-14 & -4196.4 & $-2.20 *$ & -5046.90 & $-2.11^{*}$ \\
\hline-13 & -4275.4 & $-2.28 *$ & -6410.70 & $-2.15^{*}$ \\
\hline-12 & -4000.6 & $-2.09 *$ & -4946.17 & -1.68 \\
\hline-11 & -4496.4 & $-2.49 * *$ & 4233.52 & 0.55 \\
\hline-10 & -4494.4 & $-2.54 *$ & 1869.90 & 0.33 \\
\hline-9 & -4321.9 & $-2.35^{*}$ & -2854.98 & -0.64 \\
\hline-8 & -4435.9 & $-2.46^{*}$ & -4715.76 & -1.50 \\
\hline-7 & -4631.9 & $-2.62 * *$ & -4092.94 & -1.78 \\
\hline-6 & -4604.7 & $-2.60 * *$ & -3693.30 & -1.58 \\
\hline-5 & -4606.9 & $-2.60 * *$ & -2395.41 & -0.63 \\
\hline-4 & -4108.9 & $-2.19 *$ & -5483.50 & $-2.04 *$ \\
\hline-3 & -4546.9 & $-2.55^{*}$ & -4025.18 & -1.02 \\
\hline-2 & -4646.9 & $-2.64 * *$ & -2665.13 & -0.69 \\
\hline-1 & -4646.9 & $-2.64 * *$ & -4231.39 & $-1.94^{*}$ \\
\hline 0 & -4356.9 & $-2.44^{*}$ & -4616.49 & -1.56 \\
\hline 1 & -4596.9 & $-2.59 * *$ & -5400.01 & -1.64 \\
\hline 2 & -4586.9 & $-2.58 * *$ & -6110.88 & $-2.23 * *$ \\
\hline 3 & -4596.9 & $-2.59 * *$ & -1514.15 & -0.26 \\
\hline 4 & -4616.9 & $-2.61 * *$ & -6379.57 & $-2.05^{*}$ \\
\hline 5 & -4611.9 & $-2.60 * *$ & -5941.45 & $-1.90^{*}$ \\
\hline 6 & -4622.9 & $-2.61 * *$ & 15353.98 & 0.98 \\
\hline 7 & -4616.9 & $-2.61 * *$ & -4038.46 & -1.71 \\
\hline 8 & 22625.73 & 1.28 & -4032.41 & -1.07 \\
\hline 9 & -4622.68 & $-2.61 * *$ & -3198.66 & -0.89 \\
\hline Event & Resignations & & Appointm & \\
\hline
\end{tabular}




\begin{tabular}{|l|r|r|r|r|}
\hline day & Abnormal trading volume & T stat & Abnormal trading volume & \multicolumn{1}{c|}{ T stat } \\
\hline 10 & -4461.66 & $-2.42^{*}$ & -4183.10 & -1.14 \\
\hline 11 & -4425.12 & $-2.44^{*}$ & -3336.87 & -0.80 \\
\hline 12 & -4515.96 & $-2.50^{*}$ & -4196.27 & -1.45 \\
\hline 13 & -4526.02 & $-2.50^{*}$ & 8886.50 & 0.68 \\
\hline 14 & -4388.22 & $-2.58^{* *}$ & -6423.85 & $-2.06^{*}$ \\
\hline 15 & -4632.55 & $-2.62^{* *}$ & -2746.40 & -0.62 \\
\hline 16 & -4357.38 & $-2.65^{* *}$ & -5145.80 & -1.49 \\
\hline 17 & -4307.5 & $-2.25^{*}$ & -5224.58 & -1.60 \\
\hline 18 & 187.4171 & 0.05 & -2240.74 & -0.58 \\
\hline 19 & -4422.66 & $-2.42^{*}$ & -4598.28 & -1.33 \\
\hline 20 & -4204.16 & $-2.88^{* *}$ & -5674.85 & $-1.89^{*}$ \\
\hline 21 & -3423.3 & $-2.71^{* *}$ & -4387.33 & -1.23 \\
\hline 22 & 44876.77 & 1.16 & -5099.41 & -1.65 \\
\hline 23 & -4684.23 & $-2.68^{* *}$ & -5643.00 & $-2.08^{*}$ \\
\hline 24 & -4271.63 & $-2.32^{*}$ & -5994.50 & $-1.90^{*}$ \\
\hline 25 & -4494.31 & $-2.50^{*}$ & -5809.44 & $-1.83^{*}$ \\
\hline 26 & -4665.31 & $-2.66^{* *}$ & -4656.73 & -1.28 \\
\hline 27 & -4684.3 & $-2.68^{* *}$ & -3001.47 & -0.71 \\
\hline 28 & -4573.8 & $-2.57^{* *}$ & -4447.77 & -1.16 \\
\hline 29 & -4679.39 & $-2.67^{* *}$ & -6442.86 & $-2.19^{*}$ \\
\hline 30 & -4678.26 & $-2.67^{* *}$ & -622.86 & -0.09 \\
\hline
\end{tabular}

Note: *,**, and $* * *$ indicate significance at the $10 \%, 5 \%$ and $1 \%$ level of significance respectively.

\section{Conclusion:-}

This study aimed at examining the stock market reaction to top management changes in the DSE. Following an event study approach, the results indicate positive abnormal returns and positive and significant cumulative abnormal returns surrounding the announcement of top management resignations. The share prices reaction was associated with negative and significant abnormal trading volume indicating lower than usual trading activities. Interestingly, the share prices reaction to top management appointments appear to be weaker as none of the abnormal return or cumulative abnormal return was statistically significant. Worth noting that the insignificant abnormal returns were not resulted from the equal dominance of the real and information component of the announcements as the results related to the trading volumes reaction to top management appointments indicate insignificant abnormal trading volume during the event window. The insignificant market reaction to top management appointments suggests that the announcement is not perceived by the market as a value relevant one. The study motivates further research on whether top management appointments are indeed value relevant. That is to say, future research is needed to examine whether there is a link between top management appointments and the future performance of the firms making the announcements in the DSE. 


\section{References:-}

1. Adams, J. C. and Mansi, S. A. (2009): CEO turnover and bondholder wealth. Journal of Banking and Finance., 33(3): $522-533$.

2. Al-Ahmad, Z. (2011): Corporate Governance Regulations and Practices: The Case of Private Banks in Syria. A paper presented at the ICEF conference, Izmir, Turkey.

3. Alves, C.F. and Dos Santos, T. (2008): Do first and third quarter unaudited financial reports matter? The Portuguese case. European Accounting Review., 17(2): 361-392.

4. Ball, R. and Brown, P. (1968): An Empirical Evaluation of Accounting Income Numbers. Journal of Accounting Research., 6(2): 159-178.

5. Bartholdy, J., Boyle, G.W. and Stover, R.D. (2003): Deposit insurance and the risk premium in bank deposit rates. Journal of Banking and Finance., 27(4):699-717.

6. Beatty R,P. and Zajac, E.J. (1987): CEO change and firm performance in large corporations: succession effects and manager effects. Strategic Management Journal., 8(4): 305-317.

7. Beaver, W. (1968): The information content of annual earnings announcements. Journal of Accounting Research., 6 (Supplement): 67-92.

8. Boeker, W. (1992): Power and managerial turnover: scapegoating at the top. Administrative Science Quarterly, 37(3): 400-421.

9. Borstadt, L. (1985): Stock price reactions to management changes. Unpublished Manuscript, University of Utah, Salt Lake City.

10. Brown, S. and Warner J. (1980): Measuring security price performance. Journal of Financial Economics., 8(3): 205258.

11. Brown, S. and Warner, J. (1985): Using daily stock returns: The case of event studies. Journal of Financial Economics., 14(1): 3-31.

12. Byrka-Kita, B., Czerwiński, M. and Preś-Perepeczo., A. (2017): Stock market reaction to CEO appointmentpreliminary results. Journal of Management and Business Administration. Central Europe., 25(2):23-42.

13. Campbell, Y. J., LO, A. W. and MacKinlay, A. C. (1997): The Econometrics of Financial Markets. New Jersey, Princeton University Press.

14. Charitou, M., Patis, A. and Vlittis, A. (2010): The market reaction to the appointment of an outside CEO: An empirical investigation. Journal of Economics and International Finance., 2(11):272-277.

15. Clayton, M. C., Hartzell, J. C. and Rosenberg, J. (2005): The impact of CEO turnover on equity volatility. Journal of Business., 78(5), 1779-1808.

16. Dahya, J. and McConnell, J.J. (2005): Outside directors and corporate board decisions. Journal of Corporate Finance., 11(1-2): 37-60.

17. Dalton, D.R. and Kesner, I. (1985): Organizational performance as an antecedent of inside/outside chief executive succession: An empirical assessment. Academy of Management Journal., 28:749-762.

18. Danisevska, P., De Jong, A. and Rosella, M.(2004): Disciplining managers: Evidence from two-tier boards. Working paper.

19. David, J. C. (2001): Dozens of Rich Americans Join in Fight to Retain the Estate Tax. New York Times: New York.

20. Dedman, E. and Lin, S.J. (2002): Shareholder wealth effects of CEO departures: Evidence from the UK. Journal of Corporate Finance., 8(1): 81-104.

21. Denis, D.J. and Denis, D.K. (1995): Performance changes following top management dismissals. The Journal of Finance., 50(4): 1029-1057.

22. Fama, E., Fisher, L., Jensen, M. and Roll, R. (1969): The adjustment of stock prices to new information. International Economic Review., 10(1): 1-21.

23. Furtado, E. P. and Karan, V. (1990): Causes, consequences, and shareholder wealth effects of management turnover: A review of the empirical evidence. Financial Management., 19(2): 60-75.

24. Furtado, E. P. and Rozeff, M.S. (1987): The wealth effects of company initiated management changes. Journal of Financial Economics., 18(1): 147-160.

25. Grusky, O. (1960): Administrative succession in formal organizations. Social Forces., 39(2):105-115.

26. Grusky, O. (1963). Managerial succession and organizational effectiveness. American Journal of Sociology, 69(1): 21-31.

27. Kang, J.K. and Shivdasani, A.( 1996): Does the Japanese governance system enhance shareholder wealth? Evidence from the stock-price effects of top management turnover. Review of Financial Studies., 9(4):1061-1095.

28. Kesner, I. F., and Sebora, T. C.(1994): Executive succession: Past, present and future. Journal of Management., 20(2): 327-372.

29. Khanna, N. and Poulsen, A. B. (1995): Managers of financially distressed firms: Villains or scapegoats? The Journal of Finance., 50(3): 919-940. 
30. Kind, A. H. and Schläpfer, Y. (2011): Is a CEO turnover good or bad news. University of Basel Working Paper., available at: http://papers.ssrn.com/sol3/papers.cfm?abstract_id=1679632

31. Landsman, W. and Maydew, E. (2002): Has the information content of quarterly earnings announcements declined in the past three decades?. Journal of Accounting Research., 40(3):797-808.

32. Lassoued, N. and Attia, M.B.R. (2013): The market effects of CEO turnover: The case of post-revolution Tunisia. Global Review of Accounting and Finance., 4(1): 85-103.

33. Li, J. (2012): The relationship between the announcements of CEO changes and stock prices. Working paper, Saint Mary's University.

34. Mahajan, A. and Lummer, S. (1993): Shareholder wealth effects of management changes. Journal of Business Finance and Accounting., 20(3): 393-410.

35. Maynes, E. and Rumsey, J. (1993): Conducting event studies with thinly traded stocks. Journal of Banking and Finance., 17(1):145-157.

36. Neumann, R. and Voetmann, T. (2005): Top executive turnovers: Separating decision and control rights. Managerial and Decision Economics., 26(1): 25-37.

37. Reinganum, M.G. (1985): The effect of executive succession on stockholder wealth. Administrative Science Quarterly., 30(1):46-60.

38. Setiawan, D. Phua, L.K. and Chee, H. K. (2011): CEO turnover and market reaction in Indonesia. Indonesian Capital Market Review., 5(2): 85-94.

39. Warner, J.B., Watts, R.L. and Wruck, K.H. (1988): Stock prices and top management changes. Journal of Financial Economics., 20(1-2): 461-492.

40. Worrell, D. L., Davidson, W. N., Chandy, P. and Garrison, S. L. (1986): Management turnover through deaths of key executives: Effects on investor wealth. The Academy of Management Journal., 29(4): 674-694. 